Chirurgia (2019) 114: 67-72

No. 1, January - February

Copyright $@$ Celsius

http://dx.doi.org/10.21614/chirurgia.114.1.67

\title{
TAAP vS. TEP in Inguinal Hernia Repair - What is the Evidence? A Single Center Experience
}

\author{
Adrian Tulin', Iulian Slavu'2, Vlad Braga ${ }^{2}$, Daniela Mihaila', Lucian Alecu' \\ 'Department of General Surgery, Prof. Dr. Agrippa Ionescu Emergency Clinical Hospital, Bucharest, Romania \\ ${ }^{2}$ Emergency Clinical Hospital, Bucharest, Romania
}

Corresponding author:

Slavu lulian, MD

Emergency Clinical Hospital, Bucharest

E-mail: Iulian.slavu@yahoo.com

Abbreviations:

TAAP - trans-abdominal preperitoneal;

TEP - totally extraperitoneal;

MOP - miopectineal orifice;

\section{Rezumat}

TAAP vs. TEP în tratamentul herniei inghinale - Ce dovezi există? Experiența unui singur centru

Scop: Evaluarea TAAP vs TEP în tratamentul herniei inghinale în ceea ce priveşte indicația şi limitele fiecărei tehnici, utilizând experiența acumulată de clinica noastră.

Material şi metodă: Studiul este retrospectiv, se extinde pe o perioadă de 4 ani şi include pacienți diagnosticați cu hernie inghinală unilaterală operată utilizând tehnica TAAP sau TEP.

Rezultate: Am identificat un număr de 40 de pacienți din care 25 operați folosind tehnica TAPP şi 15 folosind tehnica TEP. Vârsta medie în grupul TAAP a fost de 42 de ani si 38 de ani in grupul TEP. Durata medie a intervenției chirurgicale pentru TAAP a fost de 52 minute; şi 62 de minute pentru TEP. Herniile inghino-scrotale mari au fost tratate folosind tehnica TAAP. Conversia de la TEP la TAAP a fost întâlnită în 2 cazuri, în timp ce conversia la chirurgie deschisă a fost întâlnită în 3 cazuri. Mortalitatea a fost 0 .

Concluzii: TAAP sau TEP sunt optiuni chirurgicale fezabile pentru a trata hernia inghinală. TEP necesită echipament specializat şi prezintă un risc crescut de sângerare când se disecă spațiul Retzius. Tehnica TAAP asociază spațiu de lucru crescut pentru a manevra instrumentele laparoscopice, dar prezintă un risc crescut de lezare a organelor abdominale.

Cuvinte cheie: TAAP, TEP, laparoscopie 


\section{Abstract}

Goals: To evaluate the indications of TAAP vs TEP in the treatment of unilateral inguinal hernia and the limitations of each technique using the experience of our clinic.

Material and Method: The study is retrospective, extends over 4 years and includes patients with unilateral inguinal hernia operated using either TAAP or TEP technique.

Results: We identified a number of 40 patients of which 25 were treated with the TAPP and 15 with the TEP technique. The mean age in the TAAP group was 42 years and 38 years in the TEP group. Mean surgery time for TAAP was $52 \mathrm{~min}$; for TEP it was $62 \mathrm{~min}$. Large inguinoscrotal hernias were operated with the TAAP technique. Conversion from TEP to TAAP was encountered in 2 cases, while conversion to open a hernia was encountered in 3 cases. No deaths were recorded in the follow-up time.

Conclusions: Both TAAP and TEP are feasible surgical options to treat an inguinal hernia. The use of the TEP technique is limited by the size of the hernia defect while the TAAP technique has the advantage of larger intraoperative field, and an increased risk of injury to major abdominal organs.

Key words: TAAP, TEP, laparoscopy

\section{Introduction}

Hernia repair is one of the most frequent surgical procedures in the world with an estimated 20 million surgeries done annually to repair parietal defects (1). This associates important cost and morbidity worldwide (2).

The constant advances in laparoscopy made it possible to treat an inguinal hernia by two different approaches known as TAAP (transabdominal preperitoneal) or TEP (totally extraperitoneal). Choosing between one or the other is still controversial as consistent data to support either one of the approaches is lacking.

Large multicenter studies compared in the past open hernia repair procedures such as Lichtenstein or Shouldice to laparoscopic techniques either TAAP or TEP and found that the rate of relapse in time did not differ $(3,4)$.

In the TAAP technique, one needs to gain access to the peritoneal cavity by creating a pneumoperitoneum. After the incision of the parietal peritoneum and sac dissection, the mesh is placed in the pre-preperitoneal space which covers if the dissection is correct the entire miopectineal orifice (MOP). At the end, the peritoneum is closed over the mesh. Some studies have reported a higher incidence of cord edema and longer operation times in TAAP due to the increased area of dissection to obtain the retroperitoneal pouch to place the mesh (4).

TEP is different from TAAP in the sense that one does not need to access the abdominal cavity, thus the risk of injury to major abdominal organs is reduced. Also, the probability to develop postoperative adherences is decreased. The mesh is placed to seal the hernia from the outside of the peritoneal cavity. Due to this fact, some studies have reported lower pain in the TEP technique (5). The anatomy in TEP is unfamiliar to the laparoscopic surgeon as the workspace is situated outside the peritoneal cavity. Due to space constraints, this technique requires longer learning curves with as many as 100 procedures to be considered an expert (5).

The goal of our study was to evaluate the TAAP and TEP techniques in the treatment of unilateral inguinal hernia with respect to indications and limitations of each procedure using the experience gained by our clinic compared with results from the literature.

\section{Material and Method}

The study structure is retrospective.The diagnosis was based on clinical history of a hernia, clinical examination and ultrasonography of the abdomen. The study 
extended over a period of four years (01.01.2015 - 31.12.2018). Data were obtained from the Clinic of General Surgery of the Emergency Clinical Hospital "Prof. Dr. Agrippa Ionescu," Bucharest, Romania. Data regarding preoperative diagnosis, age, gender, hernia type, the surgical technique, intra-operative and postoperative complications, duration of the procedure, postoperative hematoma and wound infection were obtained from operative protocols, patient charts, and laparoscopic recordings.

\section{Inclusion Criteria}

Diagnosis of an inguinal hernia operated with minimally invasive techniques either TAAP or TEP, age over 18 years.

\section{Statistical Analysis}

IBM SPSS version 20.0 tool was used for statistical analysis. Data is presented as absolute frequencies or mean $\pm \mathrm{sd}$. Student $\mathrm{t}$ test was used to determine whether a statistically significant difference exists between the groups regarding age and surgery duration. One way ANOVA test was used to compare lenght of hospital stay between the TEP and TAAP groups. The threshold for statistical significance was set at 0.05 .

\section{Ethics}

The retrospective analysis of the data has been approved by a Ethics Committee of the institution within which the work was undertaken and it conforms to the provisions of the Declaration of Helsinki.
Table 1. Mean age distribution in the two groups: TAAP or TEP

\begin{tabular}{lcc}
\hline AGE (years) & TAAP - no. & TEP - no. \\
\hline Under 40 & 14 & 10 \\
\hline $40-60$ & 11 & 5 \\
\hline Mean \pm sd & $42.2 \pm 7.5$ & $38.9 \pm 5.6$ \\
\hline
\end{tabular}

\section{Results}

We identified a number of 40 patients, of which 27 were operated with the TAAP technique and 13 with the TEP technique.

The group consisted mainly of men $(n=28)$ and $\mathrm{n}=12$ female.

The majority of the patients in both groups TAAP or TEP were in the under 40 years age group (Table 1). Mean age in the TAAP group was $42.2 \pm 7.5$ years and $38.9 \pm 5.6$ years in the TEP group. There is no statistical significant difference between the groups regarding age (Student t-test, $\mathrm{p}=0.52$ ).

All of the patients presented with inguinal pain at exertion as one of the admission diagnostics.

Two patients had an incarcerated hernia in the TAAP group and none in the TEP group.

The majority of the hernias operated were indirect, lateral hernias $\mathrm{n}=23$ (Table 2).

Mean surgery time was $52.4 \pm 10 \mathrm{~min}$. for TAAP and $62.3 \pm 18 \mathrm{~min}$. for TEP. Although operative time was increased when the TEP technique was used the differences were not statistically significant (Student t-test, $\mathrm{p}=0.09$ ).

Two patients were converted from TEP to TAAP due to peritoneal tearing when dissecting the preperitoneal space.

Three patients: one in the TAAP group and two in the TEP group were converted to open hernia repair due to elevated carbon dioxide levels. The patients converted to open hernia

Table 2. Distribution of techniques (TAAP or TEP) regarding hernia location according to the European Hernia Classification (EHC)

\begin{tabular}{lcccccc}
\hline Technique & \multicolumn{3}{c}{ TAAP } & & TEP & \\
\hline Total $\mathrm{PL}=23$ & $\mathrm{PL} 1=5$ & $\mathrm{PL} 2=8$ & $\mathrm{PL} 3=3$ & $\mathrm{PL} 1=4$ & $\mathrm{PL}=2$ & $\mathrm{PL}=1$ \\
\hline Total $\mathrm{PM}=17$ & $\mathrm{PM} 1=4$ & $\mathrm{PM}=6$ & $\mathrm{PM} 3=1$ & $\mathrm{PM} 1=4$ & $\mathrm{PM}=2$ & $\mathrm{PM} 3=0$ \\
\hdashline & & Total TAAP $=\mathbf{2 7}$ & & & Total TEP $=\mathbf{1 3}$ & \\
\hline
\end{tabular}

$\mathrm{P}=$ primary hernia, $\mathrm{L}=$ lateral/indirect hernia, $\mathrm{M}=$ medial/direct hernia. Size of defect: $1 .<1,5 \mathrm{~cm}, 2 .<3 \mathrm{~cm}, 3 .>3 \mathrm{~cm}$. 
repair from the TEP group had a ruptured peritoneum which led to an unwanted pneumoperitoneum. These surgical interventions were finalized using the Lichtenstein II tension-free technique with polypropylene mesh.

There were no important visceral or important blood vessels injuries in the studied group although troublesome bleeding was encountered when dissecting the Retzius space in the TEP technique which led to an increase in surgery time due to the fact that vision of the operative field was impaired. Also, other sources of bleeding encountered were the "corona mortis"vascular anastomosis and inferior epigastric artery (1 case - the vessel was clipped and resected).

Subcutaneous emphysema was observed in one case of the TEP procedures which subsided within 24 hours of surgery.

There were no recorded wound infections in the study group. Two patients had postoperative wound discharge but bacterial cultures from the discharge liquid tested negative.

There were no recorded deaths in the study group.

We systematically used closed drainage tubes after TEP techniques. After TAAP, the Douglas space was drained using open drainage systems. The tubes were extracted one day after surgery. We did not encounter complications such as infections related to elective drainage. Patients tended to report discomfort or pain due to the drainage tubes, symptoms which subsided when the tubes were removed.

Mean hospital stay did not differ significantly between the two groups although it was slightly lower in the TEP group $(\mathrm{p}=0.7$ one-way ANOVA test) (Table 3).

\section{Discussion}

Inguinal hernias merit the use of minimally invasive techniques to treat when the advan-

Table 3. Mean postoperative hospital stay

\begin{tabular}{lcc}
\hline Days & TAAP & TEP \\
\cline { 2 - 3 } & $2.4 \pm 1.2$ & $1.8 \pm 0.8$ \\
\hline
\end{tabular}

tages of minimally invasive techniques are taken into account such as reduced incidence of wound infection and abscess, reduced period of hospital stay, faster ambulation and lower recurrence rate $(6,7)$.

The operative technique used by the authors either TEP or TAAP was standard with that described in the literature $(8,9)$.

The most important approaches to laparoscopic inguinal hernia repair are the TAAP and TEP techniques which vary regarding the approach to the inguinal defect. Of great importance when comparing these two techniques is the difficulty or ease to accomplish them. Measurement is highly subjective and difficult to obtain due to the fact that such a parameter cannot be clearly defined and depends on multiple variables such as ease of access to the operative field, preperitoneal space creation, type of hernia, frequency and severity of iatrogenic injury to surrounding structures, difficulties encountered during mesh placement due to the use of fixation devices such as tacks, sutures or glue. These factors impact the technique itself but for the patient, the most important aspects are postoperative pain and the rate of recurrence.

The corner-stone to which the success rate of a laparoscopic hernia repair depends is the creation of an adequate work space for a safe dissection and fast management of intraoperative incidents. How one achieves this is one of the important factors when comparing these two techniques. The use of a special balloon to dissect the preperitoneal space increases the cost of the TEP technique but it decreases the operative time and risk of bleeding. The balloon is not mandator for this technique as one can use a swab to dissect but this increases the difficulty of the procedure. One needs to obtain a proper space to work as to correctly identify the anatomical landmarks (10).

Some of the important factors which lead to conversion from TEP to TAAP as reported by Ferzli et al. are peritoneal tears which can have an incidence of $11 \%$, bleeding and local adhesions due to prior surgeries which use the preperitoneal space like for example, prostatectomies (11). 
We had two conversions in our series from TEP to TAAP. Both were the consequence of peritoneal tearing with secondary unwanted pneumoperitoneum which compromised the working space. It has been suggested by Zhang et al that the incidence of peritoneal tears may be decreased by a medial approach to dissection of the preperitoneal space when compared to the lateral approach (12).

As observed, most of the difficulties encountered are related to space creation, this is why we consider the balloon to dissect the prepreperitoneal space as an important equipment piece. In the TAAP technique, this troublesome complication is avoided. There is enough free space in the peritoneal cavity to maneuver with ease the laparoscopic instruments.

Vascular injuries are of utmost importance in laparoscopy due to the restricted space to stop the bleeding. Inferior epigastric artery injury is reported more commonly in the TEP technique than TAPP with an incidence of $0.3 \%$ $(13,14)$. The inferior epigastric artery serves as a landmark to differentiate direct from indirect hernia and for the dissection of the hernia sack. In laparoscopy the chances to encounter this complication are greater than in open hernia repair. One can injure the inferior epigastric artery in TEP when the sack is being prepared or the tacks are applied to the artery wall. In the TAPP technique, the risk to injure the inferior epigastric artery is the greatest when the peritoneal flap is created.

Operating time in TEP was slightly increased when compared to TAAP. This increased time is attributed to the increased difficulty at dissection and limited workspace as reported in a meta-analysis by Bracale et al. (15). Data in literature is contradictory, other authors report shorter surgery time for TAAP, thus it is difficult to evaluate this factor as it is often surgeon dependent (16).

Fixation of the mesh in laparoscopic inguinal repair still raises issues as some authors argue that in TEP it is not necessary due to the risk of nerve damage with consequently chronic inguinal pain (17). In our study, the parietal defect was covered in all cases with polypropylene mesh and fixed with tacks placed in safe points. The choice of mesh fixation depended on the surgeon as some used fibringlue.

TAPP required more tacks than TEP due to the fact that they were used to fix the peritoneal flap butone can use just as simple a continuous suture. These extra costs can be regarded as a minus for TAAP, but on the other hand, TEP requires other specialized equipment for dissection such as the balloon as we have mentioned.

We systematically drained after TEP surgery. Recent evidence suggests the rate of infection and seroma formation is decreased when closed suction drainage systems are used (18). We are in agreement with these observations, in the study group we did not ecounter mesh related infections.

Laparoscopic hernia repair is mentioned in literature more frequently as one-day surgery (19). This is true in most cases, but a safety protocol has to be followed when deciding to discharge the patient in 24 hours. In our experience, the patient can be mobilised 5-6 hours after surgery under direct supervision, but there must be constant communication between the anesthesiologist, surgeon, patient, and family of the patient.

Postoperative pain is one of the most important aspects for the patient after he/she undergoes surgery, and can become one of the determinants to choose between TAAP and TEP. Literature reports that pain scores are lower after TEP procedures, due to the fact that there is no peritoneal perforation and a smaller area of dissection (20). Unfortunately, due to the retrospective nature of our study we could not evaluate this factor.

Deep mesh infections in modern laparoscopic surgery are rare, and there is no difference in incidence between the two techniques reported in literature (4).

The TEP technique is usually avoided in large parietal defects while large inguinoscrotal hernias are often repaired with the TAAP technique as we observed in our study. Literature reports the same observations (21).

There is an extensive decision-making strategy published by Köckerling Fet al. when to use TAAP or TEP technique (22). Various 
factors are taken into account, but surgeon experience seems to play a key role (22). It is our opinion that in large inguinoscrotal hernias which are present for many years with extensive local adherences, an open Lichtenstein procedure assures the best results for the surgeon and the patient.

The study has the limits of a retrospective study as we could not oversee the diagnostic accuracy and that of record keeping. Also, the technique used to operate either TEP or TAAP was adopted in a nonrandomized manner and was fully dependent on the surgeon. Due to the lack of data, we could not evaluate postoperative pain-scores and recurrence rate.

\section{Conclusion}

In conclusion, either TEP or TAPP both are feasible surgical options to treat an inguinal hernia. Advantages and disadvantages vary: TEP requires specialized equipment and is practiced in lateral hernias, there is an increased risk of bleeding when dissecting the pre-peritoneal space. The TAAP technique comes with the advantage of increased workspace to maneuver the laparoscopic instruments but presents an increased risk to injure major abdominal organs. Due to the use of more tacks in TAAP to cover the mesh with peritoneum the costs are increased.

\section{Conflict of Interest}

The authors declare no conflicts of interests.

\section{References}

1. Kingsnorth A, LeBlanc K. Hernias: inguinal and incisional. Lancet. 2003;362:1561-1571

2. Teodorescu M1, Mogos DL, Paun I, Florescu M, Mogos D. The experience at the 4th Surgery Department of the University Hospital C.F. Craiova in the surgical treatment of inguinal hernia Chirurgia (Bucur). 2005;100(6):551-5. Romanian

3. Bittner R, Schwarz J. Inguinal hernia repair: current surgical techniques. Langenbecks Arch Surg. 2012;397(2):271-82.

4. Wake BL, McCormack K, Fraser C, Vale L, Perez J, Grant AM Transabdominal pre-peritoneal (TAPP) vs totally extraperitoneal (TEP) laparoscopic techniques for inguinal hernia repair. Cochrane
Database Syst Rev. 2005;(1):CD004703.

5. Morales-Conde S, Socas M, Fingerhut A. Endoscopic surgeons' preferences for inguinal hernia repair: TEP, TAPP, or OPEN. Surg Endosc. 2012;26(9):2639-43.

6. Salvilla SA, Thusu S, Panesar SS. Analysing the benefits of laparoscopic hernia repair compared to open repair: A meta-analysis of observational studies. J Minim Access Surg. 2012;8(4):111-7.

7. Bhandarkar DS1, Shankar M, Udwadia TE. Laparoscopic surgery for inguinal hernia: Current status and controversies". J Minim Access Surg. 2006 Sep;2(3):178-86.

8. Carter J, Duh QY. Laparoscopic repair of inguinal hernias. World J Surg. 2011;35(7):1519-25.

9. Lal P, Kajla RK, Chander J, Ramteke VK. Laparoscopic total extraperitoneal (TEP) inguinal hernia repair: overcoming the learning curve. Surg Endosc. 2004;18(4):642-5.

10. Cohen RV, Alvarez G, Roll S, Garcia ME, Kawahara N, Schiavon CA, et al. Transabdominal or totally extraperitoneal laparoscopic hernia repair? Surg Laparosc Endosc. 1998;8(4):264-8.

11. Ferzli GS, Khoury GE. Treating recurrence after a totally extraperitoneal approach. Hernia. 2006;10(4):341-6. Epub 2006 Jul 4.

12. Zhang $\mathrm{H}$, Lin J, Liao Q, Xie N, Gui X, Li J, et al. Totally extraperitoneal laparoscopic hernioplasty: the optimal surgical approach. Surg Laparosc Endosc Percutan Tech. 2009;19(6):501-5.

13. Garg P, Rajagopal M, Varghese V, Ismail M. Laparoscopic total extraperitoneal inguinal hernia repair with nonfixation of the mesh for 1,692 hernias. Surg Endosc. 2009;23(6):1241-5.

14. Ferences Spaw AT, Ennis BW, Spaw LP. Laparoscopic hernia repair: the anatomic basis. Journal of Laparoendoscopic. J Laparoendosc Surg. 1991;1(5):269-77.

15. Bracale U, Melillo P, Pignata G, Di Salvo E, Rovani M, Merola G, et al. Which is the best laparoscopic approach for inguinal hernia repair: TEP or TAPP? A systematic review of the literature with a networkmeta-analysis. Surg Endosc. 2012;26(12): 3355-66.

16. Chen LS, Chen WC, Kang YN, Wu CC, Tsai LW, Liu MZ. Surg Endosc. Effects of transabdominal preperitoneal and totally extraperitoneal inguinal hernia repair: an update systematic review and meta-analysis of randomized controlled trials. 2019;33(2):418-428.

17. Buyukasik K, Ari A, Akce B, Tatar C, Segmen O, Bektas $H$. Comparison of mesh fixation and non-fixation in laparoscopic totally extraperitoneal inguinal hernia repair. Hernia. 2017;21(4): 543-548.

18. Ismail M, Garg M, Rajagopal M, Garg P. Impact of closed-suction drain in preperitoneal space on the incidence of seroma formation after laparoscopic total extraperitoneal inguinal hernia repair. Surg Laparosc Endosc Percutan Tech. 2009;19(3):263-6.

19. Lorente-Herce JM, Marín-Morales J, Jiménez-Vega FJ, Ruíz-Juliá ML, Claro-Alves BM, Fernández-Zulueta A, et al. Laparoscopic incisional hernia repair in an ambulatory surgery-extended recovery centre: a review of 259 consecutive cases. Hernia. 2015; 19(3):487-92.

20. Bansal VK, Misra MC, Babu D, Victor J, Kumar S, Sagar et al. A prospective, randomized comparison of long-term outcomes: chronic groin pain and quality of life following totally extraperitoneal (TEP) and transabdominal preperitoneal (TAPP) laparoscopic inguinal hernia repair. Surg Endosc. 2013:27(7):2373-82.

21. Köckerling F, Bittner R, Jacob DA, Seidelmann L, Keller T, Adolf D, et al. TEP versus TAPP: comparison of the perioperative outcome in 17,587 patients with a primary unilateral inguinal hernia. Surg Endosc. 2015;29(12):3750-60.

22. Köckerling F, Schug-Pass C. Tailored approach in inguinal hernia repair-decision tree based on the guidelines. Front Surg. 2014;1:20. 